Tale ved åbningen af udstillingen i Det kongelige Bibliotek Fiolstræde 2. dec. 1993:

\title{
Glimt fra avisens historie
}

af mag.art. Jette Drachmann Søllinge

Mine damer og herrer -!

Hensigten med udstillingen er at belyse pressens historie. Da denne historie rækker fra 1634 eller endnu før og til idag, og da man dårligt kan se presseskoven for bare blade, er det plat umuligt at belyse pressehistorien i sin helhed og alle sine aspekter. Derfor er valget faldet på at samle sig om en bestemt vinkel på udstillingen. Denne vinkel er til gengæld også central: Nemlig udviklingen ibredden af pressens indhold, d.v.s. hvad der rent faktisk står i aviserne.

Det kan lyde som en lige så voldsom mundfuld, men lykkeligvis har aviserne været så venlige at falde i nogenlunde afgrænsede typer. Hver tidsperiode har desuden sine traditioner for, hvad aviser bør og kan og skal skrive om. Udstillingen handler derfor om de vekslende pressetyper.

Der var udelukkende udenrigsnyheder i de allerældste aviser. Siden er emnekredsen blevet dramatisk udvidet, så der i dag næppe findes noget menneskeligt, der er fremmed for avisen.

I 1634 udstedte Christian IV det første avisprivilegium til d'herrer Martzan og Moltke. Den lille avis med udenrigsstof er kun bevaret i enkelte numre et par kan ses i en af montrerne. Men den lille publikation var i virkeligheden en revolution, idet de eneste trykte nyhedsberetninger hidtil havde været flyveblade, der kun bragte een beretning og udkom uregelmæssigt. Fra 1634 var nyhedsformidling i princippet lagt i forudsigelige rammer - der udkom gerne et nummer af avisen hver uge.

Omkring 1665 begyndte aviserne at komme i faste rammer, og der ud- 


\section{4.) Jilli, STratice; \\ Extraordinaires \\ sqaanedlige \\ RELATIONER \\ fom ere frementomere 1 \\ JULII-Sraanet \\ Anno 1674.}

177

\section{Sanmarct.}

\section{Sínbentiafit.}

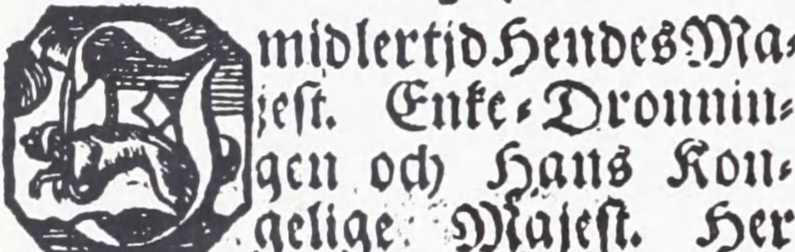
Broder Dertiosescorg vale paa Fllac / hafue fammeltado bos

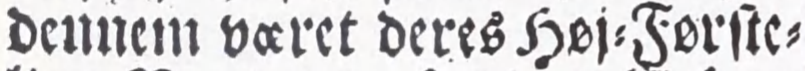
lige Raadel: Sjertig Goban

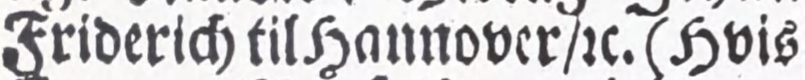
Enboye Dionl. s)?andels lo vat

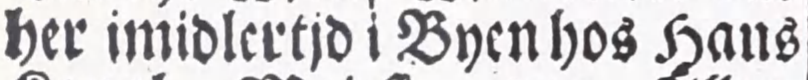
Kontgl. Majeft. vor saller: Itaabigfte Serve ) Sertug (Eblis

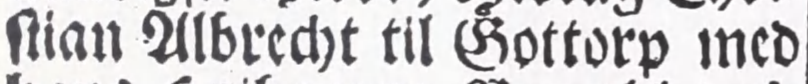

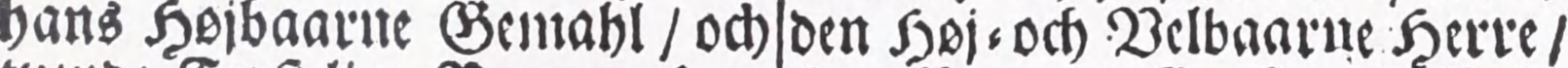

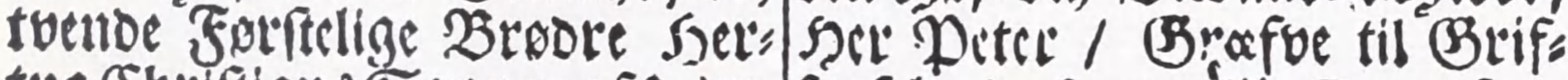

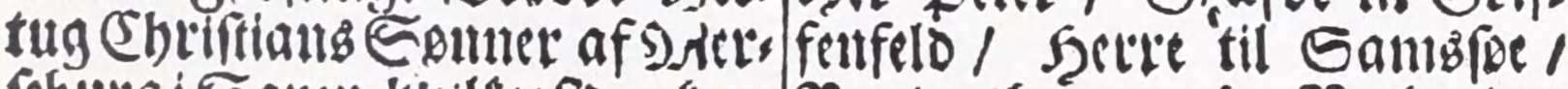

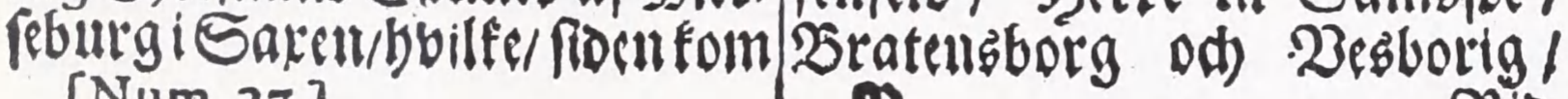

$$
\text { [Num, 23.] }
$$

bjo til Byen at opvalte 5.R.M2? Efter nogle Dage bafue diffe twende Farfel. Srebde taget alffeco bos beyeftocmalate Songl. Mai. til Friderid) bobrig od) begifuet denment paa deria Reyle igien ad Ganliborg.

Den ro. Junii om morgenen

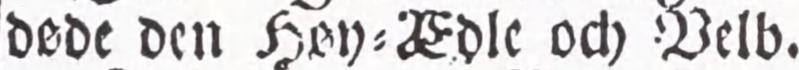
ati Sal. Sot'l / S. Deter Reez til Illlebyebolm / ac.2c.Rioderl

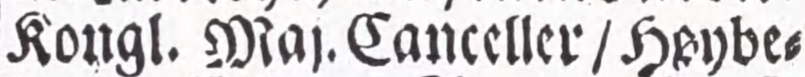
troco Bebcime Rand / Ṕlafi. dent i Enll. lli: Eollenio

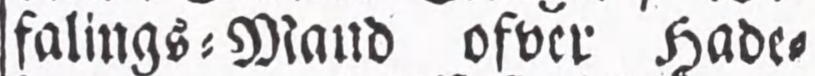
[and/2c.26. odb 21feffor i collegio Stattig ndt boverte Rat / oc Cl (3)

Merkur var skytsgud for handelsmænd, tyveknægte - og blev siden tillige journalisternes beskytter. De vingede sko var tegnet på den hurtige bevægelighed, som er nyhedsformidlingens kendemærke. Derfor er et billede af Merkur en sædvanlig vignet på flere af de allerældste avisers forsider, ligesom flere avistitler hed noget med Mercurius. På det bånd, han holder i hånden, står: "Relata refero" - d.v.s. "jeg fortæller videre, hvad jeg har fået berettet". 
vikledes hurtigt et system, som viste sig brugbart det næste hundrede år. Avisudgiverne begyndte at opdele deres udgivelser i ugeaviser, der udkom en eller to gange om ugen i en dansk og en tysk udgave - samt månedsaviser med en nyhedsoversigt samt de officiøse meddelelser, der skulle bringes $\mathrm{i}$ følge privilegierne. Tillige begyndte der at komme indenrigsstof $i$ aviserne. Omkring år 1700 så man også det første egentlige kulturstof. Men det er karakteristisk, at kulturstoffet i første ombæring fandt spalteplads i særlige blade, ene helliget kulturstof. Det samme gjaldt mange af de andre nye emner, aviserne begyndte at beskæftige sig med senere.

Fama var gudinde for rygtet og berømmelsen og derfor en naturlig ingrediens $i$ et avishoved i en tid, hvor en væsentlig del af nyhedsformidlingen beskæftigede sig med skelsættende udenrigsbegivenheder og fyrstehusenes forhold. (Her fra "Die Dänische Fama", der udkom 1731-95 og mest bragte udenrigsnyt). Denne Fama var tillige udstillingens logo på plakat og forsiden af brochure.

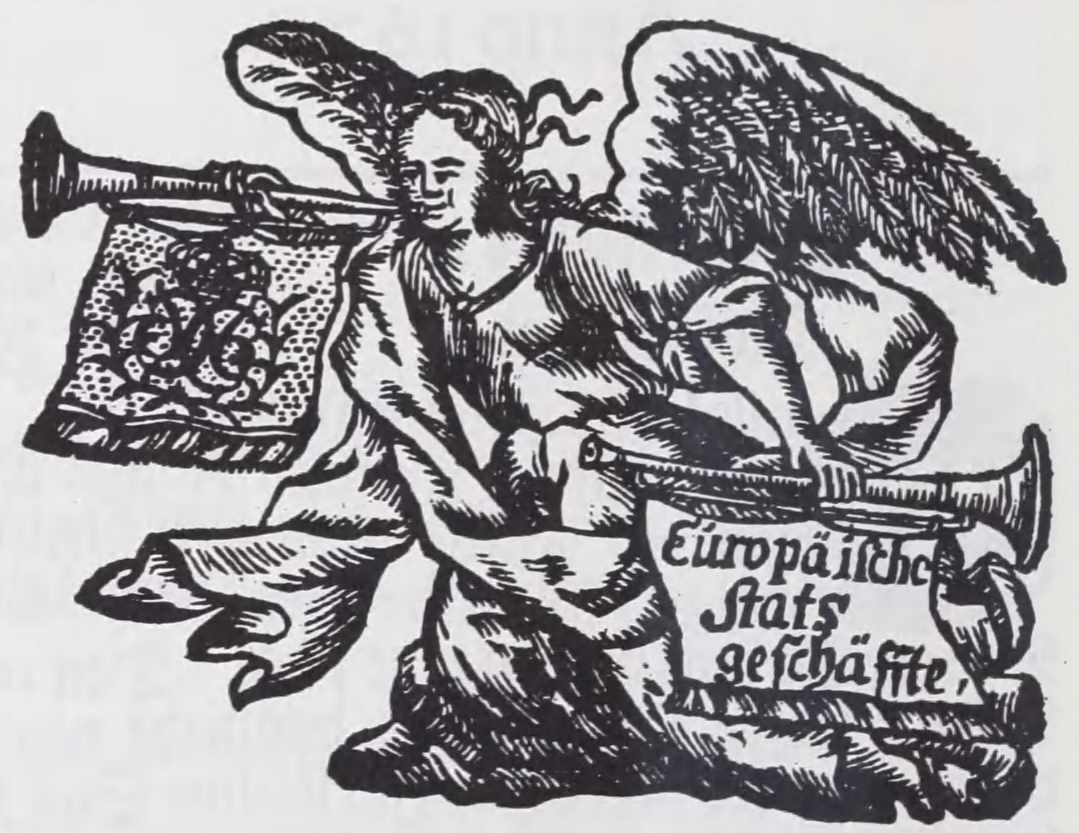

Men aviserne var under censur, og debat om politiske emner var ikke velset. I1740'erne begynd teen samfundsdebat for første gang at finde udtryk i pressen. Der var kun tale om blade, der var loyale overfor regeringsformen. Men dog betegnede de et stort gennembrud ved overhovedet at tage sådanne emner til debat. Den franske revolution udkrystalliserede nogle tanker, der allerede lå latent mange steder. Kort efter kom endnu et af pressehistoriens væsentlige gennembrud: De første oppositionelle aviser så dagens lys.

Oprindelig udkom samtlige danske aviser fra København. Det første forsøg på at skabe en avis uden for København kom i Odense 1735. Det var en pauver sag, der kun holdt ca. 15 år. Den ligger til beskuelse i en af montrerne.

Siden kom der mere vellykkede forsøg - allerede nr. 2 var en succes og udkommer den dag i dag: Aalborg Stiftstidende, der de første år hed Nyttige og fornøyelige Jydske Efterretninger. 


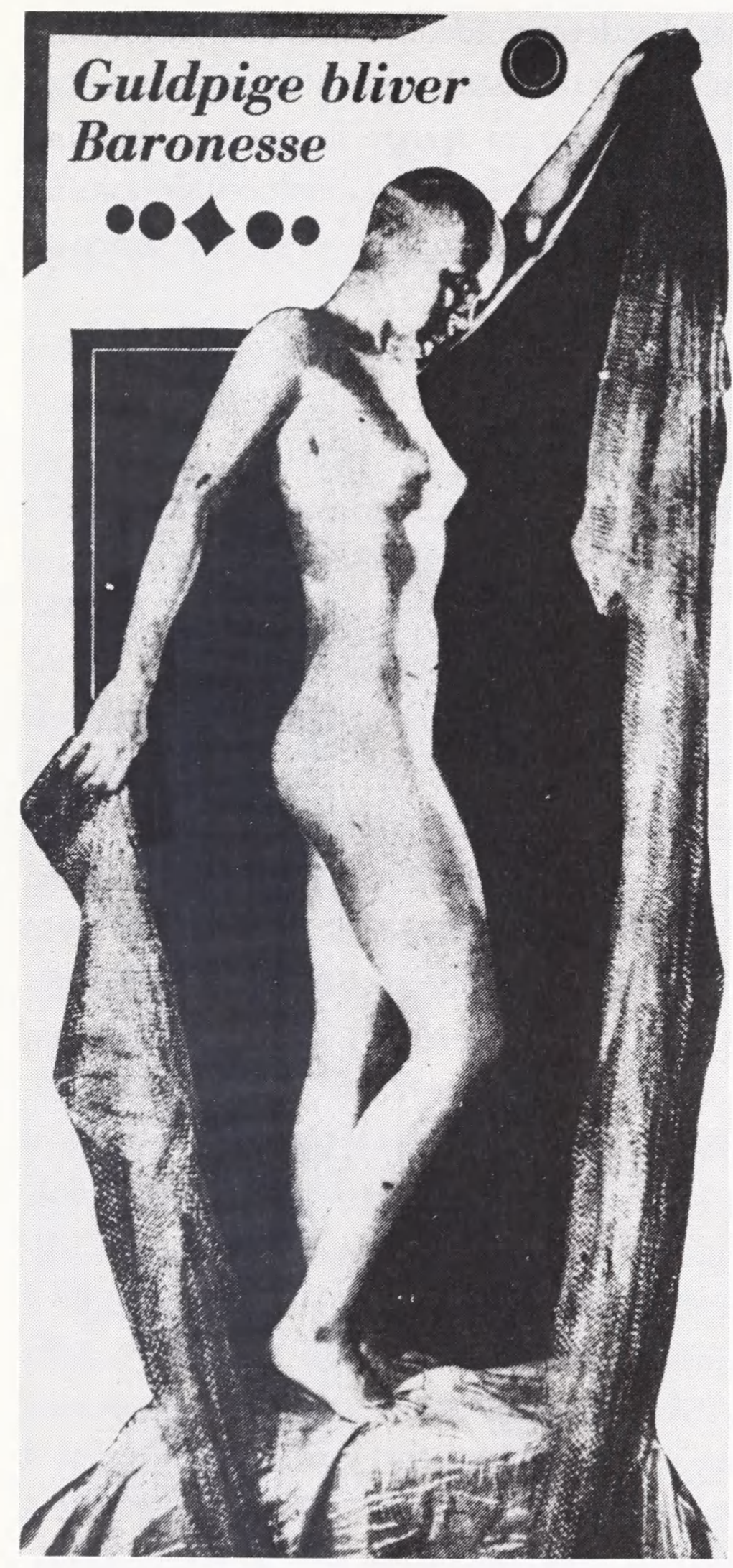

Billeder blev først fast bestanddel i de mere underholdningsprægede aviser, siden også i de mere bevidst seriøse. I 1930'erne indførte Ekstra Bladet en hel billedside (bagsiden). Og hvis nogen tror, at mere eller mindre afklæd te piger er en total nyhed, kan de tro om igen. [Ekstra Bladet, 23.11. 1937].
Censuren blev afskaffet $\mathrm{i}$ 1848 - og den politiske debat blev fri. Her så man endnu en af de virkeligt store omvæltninger i dansk presse. Den politiskedebatblev herefter helt central for pressen, der blev talerør for de forskellige politiske interesser. I provinsen blev det til "fireblads-systemet", hvor fire aviser af forskellig politisk holdning konkurrerede om læserne i selv ret små byer med deres opland. Debatten var ofte ophedet - det hang naturligt sammen med heftigheden i den magtkamp, der fulgtes ad med samfundets omlægning fra agrarsamfund til industrisamfund.

På et tidspunkt kort efter 1900 fandt man en ny modus vivendi: indførelsen af folketingsparlamentarismen var på sæt og vis blot det formelle udtryk for den ny orden. Den politiske polemikblev nedtonet, og læserne forlangte nu flere og mere varierede nyheder. Sam- 
men med tekniske omlægninger blev det en voldsom udfordring for pressen. Fra at være opinionspresse skulle den nu omstille sig til at bringe væsentligt større mængder alsidig nyhedsdækning fra mange forskellige områder, baggrundsorientering og en mængde servicestof. Det krævede flere journalister, nye maskiner, etc. Det var dyrt, så der skulle hverves flere læsere og flere annoncører til at betale regningen.

Det førte til voldsomtskærpet konkurrence på indholdet-og bladdød. Fra 159 selvstændige aviser på toppunktet i 1919 faldt antallet til 42 idag. Mens der tidligere var fire blade i hver en by, er der nu kun een med lokalt monopol, der på tværs af partigrænser skal betjene alle byens indbyggere. Til gengæld er de overlevende meget større og når langt flere læsere, trods presset fra radio og TV.

Fra det rå, ubearbejdede udenrigsstof på fire sider til den nuværende avis med alle dens mangeartede emner og store omfang - denne udvikling har sammenhæng med, at samfundet er blevet stadig mere kompliceret. Alle dage har folk kun behøvet at læse om, hvad de ikke ved i forvejen. Før i tiden kendte folk glimrende til, hvad der foregik i byen - de skulle læse avis for at få noget at vide om, hvad der skete i udlandet. I dag behøver f.eks. erhvervsfolk aviser for at få kendskab til, hvad der foregår inden for deres egen branche.

Gennem tiden har pressen fået stadig større indflydelse, og journalistik er blevet en agtet profession. Der tales om pressen som den kontrollerende fjerde statsmagt ved siden af den lovgivende, den udøvende og den dømmende. Især i forbindelse med krigskorrespondance tales også om pressen som den femte våbenmagt. En satirisk tegning fra for et par år siden viste et militært rekrutteringskontor, hvor den unge håbefulde bliver spurgt om, hvilket værn han helst vil optages i: Svaret er CNN.

I bladhovedet på mange af de helt gamle aviser finder man en af to gennemgående vignetter: Den ene er Merkur - gud for handelsmænd, tyve og journalister. Den anden er Fama - rygtets og berømmelsens gudinde. Det er hende, der ses på udstillingsfolderens forside. Her på udstillingen, der skal fejre Det kongelige Bibliotek, er detaltså Fama, der får lov at råde: berømmelsens Fama! 